\title{
The development of a Nexus based green architecture ranking system in Iran
}

\author{
Nima Norouzi ${ }^{1}$, Maryam Fani $^{*},{ }^{,}$Zahra Nasiri ${ }^{2}$ \\ ${ }_{1}$ Department of energy engineering and physics, Amirkabir university of technology (Tehran polytechnic), Tehran, Iran. \\ ${ }^{2}$ Department of Architecture, Islamic Azad university: Ardabil Branch, Ardabil, Iran
}

\section{Keywords}

Sustainability,

Green Building,

Ranking Systems,

Energy Audit,

MENA.

\begin{abstract}
The concept of green architecture, also known as "sustainable development" or "green building," is the theory, science, and style of buildings designed and built based on environmentally friendly principles. Green architecture seeks to minimize the number of resources used in the construction, operation, and management of the building and limit the damage caused to the environment by spreading, pollution, and waste of building components. New water and materials are used to design, build, operate and conserve building energy and generate large amounts of waste that negatively affect health and the environment. To limit these effects and design environmentally sound and resourceefficient buildings, the concept of "green building systems" needs to be introduced, clarified and understood, and practiced. One of the solutions is to use green building methods in the construction industry in today's world. Demand for sustainability as a definitive solution to all environmental challenges Inspired by this research to emphasize the priority of increasing sustainable environmental productivity to reduce carbon emissions to discuss and demonstrate sustainable buildings in Iran (new and existing) and Presenting the principles of energy audit used in them and their performance toward standards. Meanwhile, Iran is ranked as one of the good countries in building growth and green energy in the Middle East and other countries, according to the US Green Building Council's ranking of energy consumption, renewable energy, and recycled materials in 2015-2016.
\end{abstract}

\section{Introduction}

Improvement is a well-known phenomenon and period for human society. However, sustainable development is an idea that has proven itself over the past five decades. since the introduction of sustainable improvement at the Stockholm convention in 1972 [1], numerous strategies have been provided regarding its nature and application. The development desires and their rules revolved around monetary prospects and targeted income generation and maximum economic returns until four many years in the past. However, within the late 20th century, to live better than the present-day situation and to create idealistic conditions for future generations, improvement, and boom had been pushed via monetary, cultural, industrial, and environmental elements.

In step with the primary article within the Rio Manifesto, man is imperative to improvement. All sports have to be directed so that a wholesome man or woman can stay and develop in a wholesome environment. Besides, similar situations must be supplied for future generations.

The idea of sustainable development changed into introduced in 1994 in Iran. To broaden suitable policies and coordinate among the Iran's socio-monetary applications, environmental dreams, and the achievements of the 1992 summit in Rio, the government of Iran has set up a "Sustainable countrywide development Committee," whose individuals have authorized representatives of the ministry of civil and power. These days, there are numerous governmental and nongovernmental organizations inside the USA [3]. There's no clear definition for sustainable development, so each corporation and organization has described the term based on its schedule and dreams.

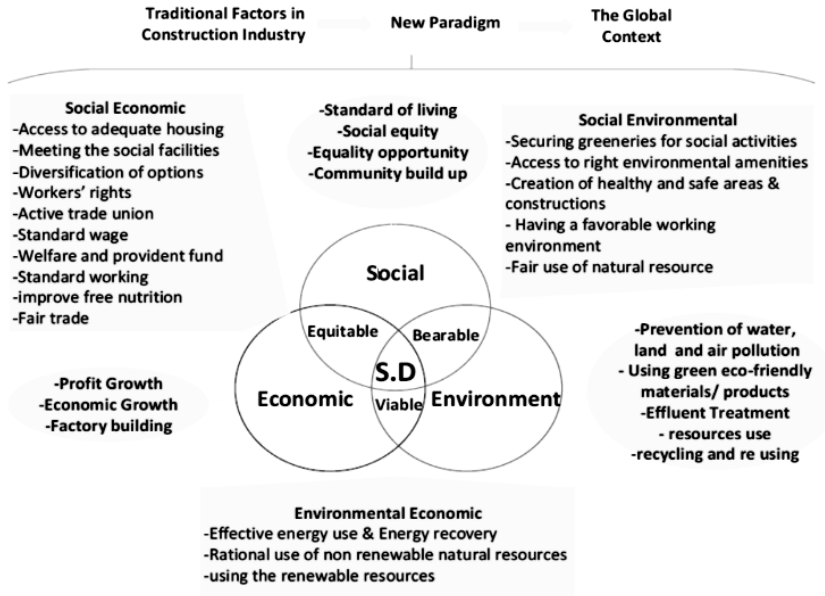

Figure 1. Sustainability and sustainable development

The term sustainable improvement changed into first brought on the 1986 international convention in a document entitled "Our commonplace destiny. "Thee 1987 Berndland convention defined sustainable development as "meeting the contemporary generation's desires without compromising destiny generations' capability to meet their needs." [5] Brandland's file explains: "Sustainable development is a set of approaches to create and maintain improvement that seeks to alleviate poverty, create the requirements of just life, meet the fundamental wishes of everybody, and create sustainable political practices for all." "It takes the essential steps to save it for you. The irreparable long-time period harm to natural capital, in flip, is to 
quick-time period benefits by reconciling the improvement project with the potential to restore the herbal surroundings."

There are numerous definitions and goals for sustainable improvement [6]. However, the commonplace denominator among all of them is summarized in sections. First, progress and development in the direction of an acceptable situation appropriate for all. 2nd, keep the proper situation for future generations. Up to now, the definitions appear clear; however, while the problem is not clean for correct definition and limitation, the trouble arises. It is unknown at the moment what he/she will do after leaving the submit. It is unknown right now what he will do after leaving the submit. Whether or not modern progress or destiny progress is greater essential in terms of precedence [7]. Eventually, the solution to the question is the cause of the examination: how to read this within the creation zone. The study presents an outline of the way sustainable rating systems assist reduce carbon emissions within the middle East and North Africa and the challenges facing architectural initiatives, even in a country like Iran that has a worldwide score system (LEED) and additionally implements the local ranking device, namely the Iranian inexperienced constructing regulations (MABHAS-19), the neighborhood standards ought to be tested and authorized with the aid of distinctive ranking structures. This look at pursuits to discuss and demonstrate Iran's sustainable homes (new and existing) and present the principles of energy performance used in them and their overall performance [8].

The idea of sustainability focuses typically on the reaction of societies to the consumption of natural resources. Nonetheless, lots of medical research has begun to research sustainability over a wide range of regions primarily based on three fundamental pillars: environmental, economic, and social. Given the interest in studies within the middle East and North Africa (MENA) place, we found that the principal purpose for innovation in new rating structures for precise nations is social culture distinction (see fig.2).

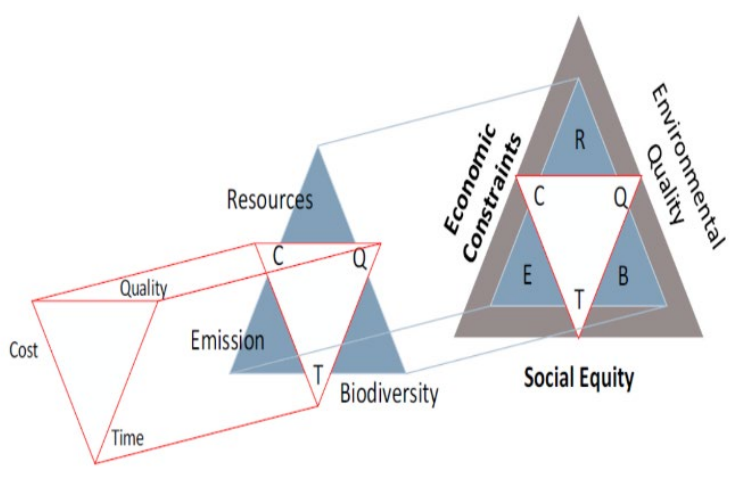

Figure 2. Pillars of the sustainability

but, the place has made full-size progress in recent years within the field of the green structure. The purpose of inexperienced architecture isn't simply green; it's miles clear that sustainable design within the location appears to be a procedure wherein designers and creative businesses discover environmentally friendly designs supplied on this studies [9].

Sustainability is one of the most vital demanding situations dealing with society today. There may be currently no consensus on improvement additives and signs. one of the Iran's principal issues is the lack of a contradiction among special sectors' dreams and activities [10]. Decision-makers must remember the development industry's dreams and pursuits at a micro and macro level to reap sustainable improvement goals [11].

Enlargement in any area necessarily calls for continuity and perseverance. Developed international locations have now recognized sustainable development as a legal right for gift and destiny generations. Iran has also taken a step in this path [12]. However, there may be a long manner to move before the beliefs of development are found out. The development sector wishes to strategize and construct the future requires large ahead-searching studies. Otherwise, destiny resources will not be available. This paper considers the opinion of experts in sensible strategies to the sustainable production enterprise. In short, this paper goal to evaluate the prevailing countrywide well-known (MABHAS-19) with worldwide standards and enhance it with a new ranking device to be adopted.

\subsection{Green buildings}

the term has spread over the last ten years among many architects and all those inquisitive about creation. However, its definition is still extraordinary from one enterprise to every other. The Federal office for the surroundings defines the term as follows: "action to boom the productivity of homes and their web sites that use strength, water, and materials, and through the vicinity, the impact of construction on human fitness and it reduces the damages to the environment and additionally unearths, design, build, function, hold and enhance the constructing's existence cycle." [13] another definition supplied through the Environmental safety agency (EPA) is as follows: "The action to create structures and use the strategies that take region all through the existence cycle of a constructing all through the lifestyles of a building from design to design, creation, operation, upkeep, preservation and reconstruction of environmentally pleasant and green resources are being performed. This movement develops and complements the issues associated with conventional homes' layout, namely financial system, equipment, sustainability, and comfort. The green building is also referred to as a solid or excessive-overall performance construction. inexperienced buildings should have the various so-called "inexperienced" features, and electricity performance is honestly one of the principal features, and some businesses, in conjunction with other features consisting of recycled substances, recycled water, and its stable device." [14]

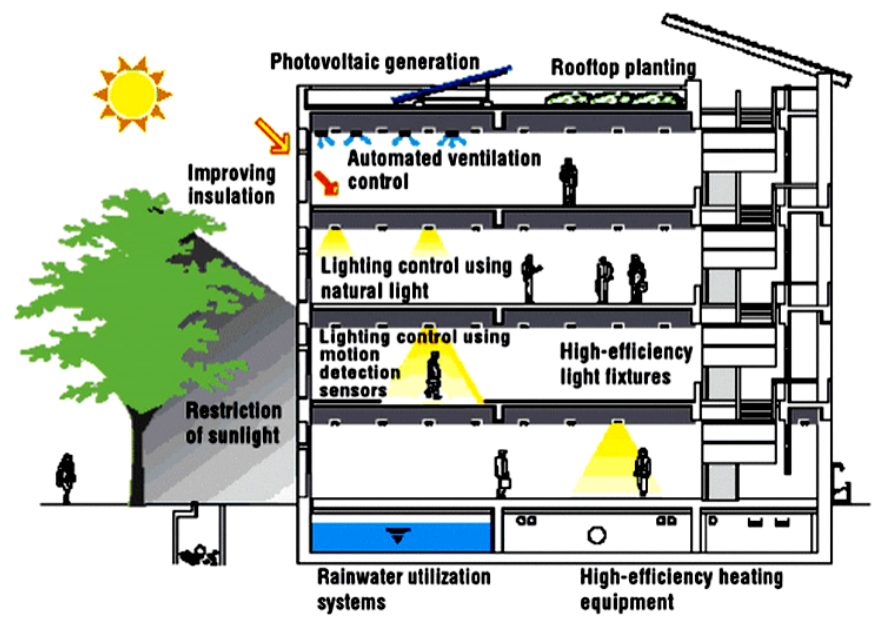

Figure 3. Conceptual Green Building schematics

Overview of green buildings or "High-Performance Buildings" means a building with high energy efficiency reflected in the environmental aspects. Although the Green Building and Technology Movement is still in its infancy, some expect it to be as inspiring and exciting as information technology changes over the past 20 years. As a result, the features of the green building are summarized in seven points (see fig. 3):

Disruption, at least for site views and conditions.

Use of non-toxic and recyclable materials.

Effective use of water and water recycling.

Use efficient energy and environmentally friendly equipment.

Use of renewable materials.

Air quality indoors for human safety and comfort.

- Effective controls and building management systems. 


\section{Regional Ranking Systems}

Many efforts have been made to define and measure environmentally pleasant design, and various score structures had been in place because the 1990s. The period "green structure" has been synonymous with environmentally pleasant architecture for the reason that Seventies. The environmentally-pleasant building is the "inexperienced building" both within the construction career and in popular lifestyle[15].

Because the term sustainability is commonly related to environmental elements, even enforcing any such concept modifications society's preferred lifestyle. The assignment dealing with maximum international locations within the region on the social stage faces a brand new era [13]. Witnessing the Earth's natural sources' limitations, particularly power sources, ought to eliminate old traditions and think. Training and the brand new generation have to follow the direction of sustainability. We see that many ranking structures within the vicinity's international locations recognize the significance of being well suited with each of Iran's lifestyle and globa requirements[15]. The three pillars of sustainability, the surroundings, the financial system, and society must have been considered in each green construction general[16]. the sector of interest of this research is the assessment of advanced ranking systems in the vicinity with the aid of authorities institutions to fulfill the social necessities of every Iran, alongside global ranking structures used for all new processes in many nations that sustainability has been considered as a priority in all new constructions[17]. The most well-known ranking systems inside the location that are presently diagnosed by way of the new projects are Stidama advanced by the Abu Dhabi urban making plans Council, ARZ developed by way of the Lebanese green building council, and GSAS, evolved by using the Qatari government, and MABHAS-19 evolved through the Iranian Engineering associationv[18]. the prevailing study seeks to research those systems collectively with a valid project from every one of them, due to the fact the full fee of infrastructure and capital projects planned and implemented within the Persian Gulf Cooperation Council (GCC) nations in 2015 is worth 172 billion USD - the highest document to date, consistent with the annual report posted by way of the Deloitte Middle East Institute [5].

The present observation analyzes the sustainability evaluation systems used inside the MENA place by focusing on the structure utilized in Iran, offers a sample for each ranking device, and compares those structures that can be designed. A more sustainable assessment device that meets Iran's situations. It should additionally be noted the differences between using previously used worldwide rating structures, such as the LEED-management system, which changed into accepted long earlier than the established order of latest ranking structures for each country (see fig. 4) $[6,18]$.

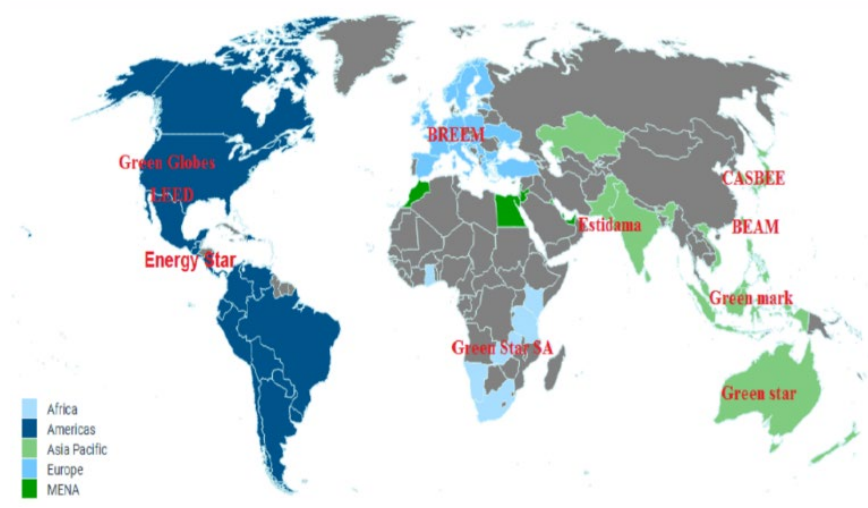

Figure 4. Atlas of the international green building standards

\subsection{Qatar Sustainability Assessment System (QSAS)}

Qatar's Sustainability evaluation gadget (QSAS) is a well-established ranking machine that evolved through the Persian Gulf research and improvement organization (GORD). This device's predominant goal is to create sustainable surroundings that, thru the improvement of a sustainable ranking system under the help of a set of overall performance-primarily based standards that deal with local wishes and Qatar's precise environment, limit organic effects and its goals [19]. These consist of decreasing operating fees, increasing asset fees, lowering waste dispatched to landfills, retaining strength and water, and presenting extra health and protection for citizens [20].

Many new homes were approved utilizing this evaluation gadget, including residential, business, mosques, education, light, and sports industries. Credit is offered in eight sections consistent with overall performance. These credits are then delivered together to earn a single standard rating on a 1 to six-star scale. A 6-famous person rating method the highest score. The GSAS certification criterion is split into eight categories, as shown in Table 1 [21].

Table 1. GSAS criteria information

\begin{tabular}{lll}
\hline Score & Criteria & Stage \\
\hline $24 \%$ & Energy & 1 \\
$16 \%$ & Water & 2 \\
$14 \%$ & Built Environment & 3 \\
$13 \%$ & Cultural values & 4 \\
$9 \%$ & Site & 5 \\
$8 \%$ & Civil Connections & 6 \\
$8 \%$ & Material & 8 \\
$8 \%$ & Management & 7 \\
\hline
\end{tabular}

Qatar's 9aaf3f374c58e8c9dcdd1ebf10256fa5 projects that have obtained the GSAS certification are a multi-cause corridor on the Lucille sports membership, designed with the aid of a KEO worldwide representative. The Qatar Olympic Committee (QOC) finished the corridor's construction at the start of 2015 for its international Handball Championship. The hall will be used for a wide range of sports activities, together with handball, basketball, volleyball, and ice skiing. The hall met the nearby and international federation requirements and received the first GSAS sports activities registration code in Qatar with four stars. The project's total area is ready 387,123 square meters and consists of the three most important homes with gentle and difficult landscaping with automobiles and parking [8]. Highlights of venture sustainability encompass $100 \%$ recycling and reuse of gray water. Decreased ingesting water consumption, a 70\% boom in glass efficiency and 36\% decrease in light energy density, $20 \%$ substances with recycled content material, $27 \%$ substances with like-minded sources with the environment, ninety\% of building materials and construction fees contributing to the national economic system the usage of local sources, $35 \%$ of substances may be separated at the stop of challenge existence, $75 \%$ waste recycling, landscaping With low water consumption and efficient recycling, low pollution after indoor paintings, warmth discount strategies together with brightly colored substances, extended balance management practices in the course of operation, the website online is enormously available and walkable by connecting to public shipping (see fig. 5)[9].

\subsection{Lebanese Green Building Council (LGBC)}

The Lebanese inexperienced constructing Council (LGBC) is a nonincome, non-governmental employer founded in 2008. the principle motive of creating ARZ as a permitted score device in Lebanon is to ensure a sure quality of lifestyles and decrease the environmental impact of the development region, one of the important motives for environmental pollution and carbon dioxide emissions surroundings [10]. 


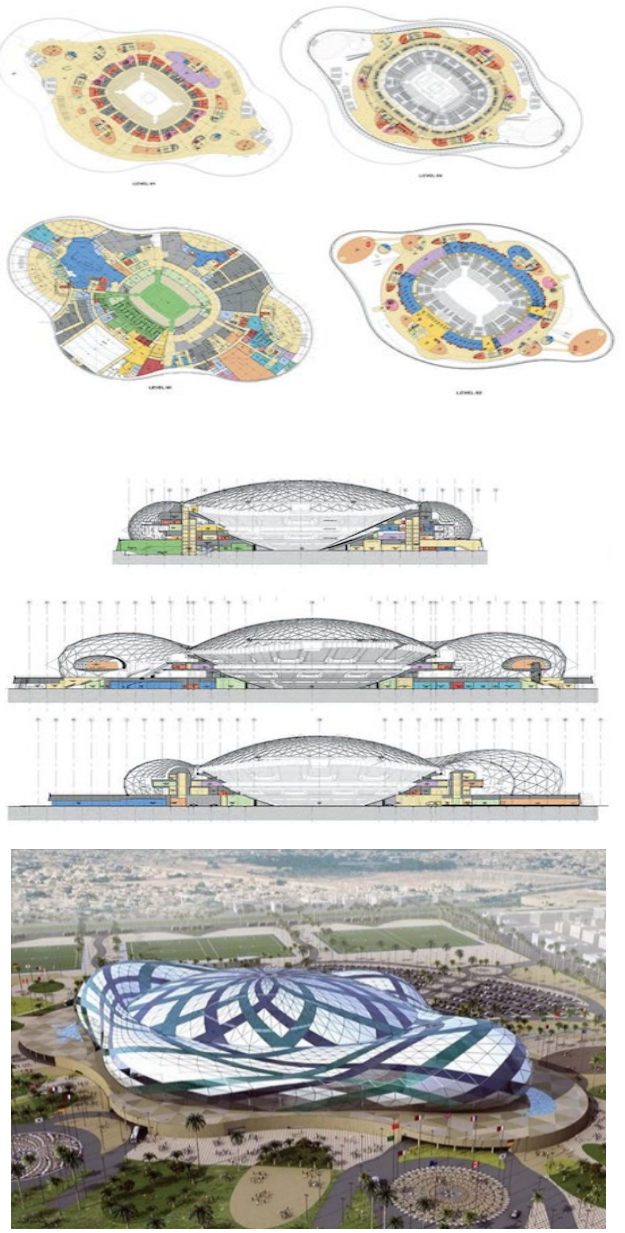

Figure 5. Lusail multi-purpose sports hall a 4-star GSAS project (source: projects official website)

The above council's project aims to perceive and sell the approaches, methods, and answers of layout, planning, production, and use of recent buildings and the predominant reconstruction of current homes to gain sustainability. Living spaces should be created in an environmentally pleasant, low-cost, and innovative way. This pliability will increase the fitness and luxury of those spaces' users (see table 2).

Table 2. LGBC building rating system module

\begin{tabular}{ccc}
\hline Maximum Score & Criteria & Module \\
\hline 6 & Energy performance & M1 \\
33 & Thermal energy & M2 \\
36 & Electrical energy & M3 \\
8 & Building facades & M4 \\
9 & Materials & M5 \\
11 & Air quality & M6 \\
9 & Management & M7 \\
60 & Water reserve & M8 \\
& Costs & M9
\end{tabular}

The primary authorized project to use the ARZ device is the BLC financial institution's headquarters in Beirut. The principle concept of this building is "sign" and a way to create this sign up the texture of the city, and on the identical time, it is in harmony with the urban layout and surrounding buildings consistent with peak and form, and the dressmaker has succeeded in making this building in the minds of all passers-through displaying a prominent constructing [11, 22].

The dressmaker even reflects the height of the construction with the aid of reflecting the visible elements of the road inside the facade of buildings with intersecting parametric strains alongside the manner and shows the character of the constructing's the feature as a bank reflecting the progressive idea no longer only in the building's outdoors and outdoors conduct. It also deals with the building's exterior design, which affects the revolutionary spirit in the minds of employees[23]

This project is an exciting image that indicates the vital financial institution's workplaces inside the twenty-first century in all feasible methods and in phrases of layout, integration of the present-day building, the way it deals with the web site, the usage of sustainability, advanced social facilities, and the way Its bold structural answer is modern, making viable the layout that is the main purpose for LGBC approval (see fig. 6)

\subsection{Article 19 of national Iranian building regulations (MBHAS)}

In Persian, MABHAS means "Articles" and is an innovative sustainability plan for the Iranian City Planning developed by the engineering association [24]. The national Iranian building regulations are a framework for design, construction, and sustainable performance in Iran. The High Engineering Executive Council has stipulated that all new communities, buildings, and villas must have a minimum acceptable MABHAS score. Government and office buildings require more score to be confirmed as an operatable building. The MABHAS Ranking System ranks the built environment's performance concerning the economic, environmental, cultural, and social aspects that fit the national community [25].

The system was first launched in 1995. There are currently 22 regulation and scoring articles:

Article 1: Basics of construction

- Article 2: Administrative systems

- Article 3: Protecting buildings from fire

- Article 4: General requirements of the building

- Article 5: Building materials and products

- $\quad$ Article 6: Loads on the building

- Article 7: foundation

- Article 8: Design and construction of buildings with building materials

- Article 9: Design and construction of reinforced concrete buildings

- $\quad$ Article 10: Steel threads

- Article 11: Industrial implementation of buildings

- Article 12: Safety and protection of work during implementation

- Article 13: design and implementation of electrical installations of buildings

- $\quad$ Article 14: Mechanical installations

- Article 15: Elevators and escalators

- Article 16: Health facilities

- Article 17: Natural Gas Piping

- Article 18: Insulation and sound regulation

- Article 19: energy audit (energy and environment)

- Article 20: signs and symbols

- Article 21: Passive Defense (social and cultural values)

- Article 22: care and maintenance of buildings (economic status) 

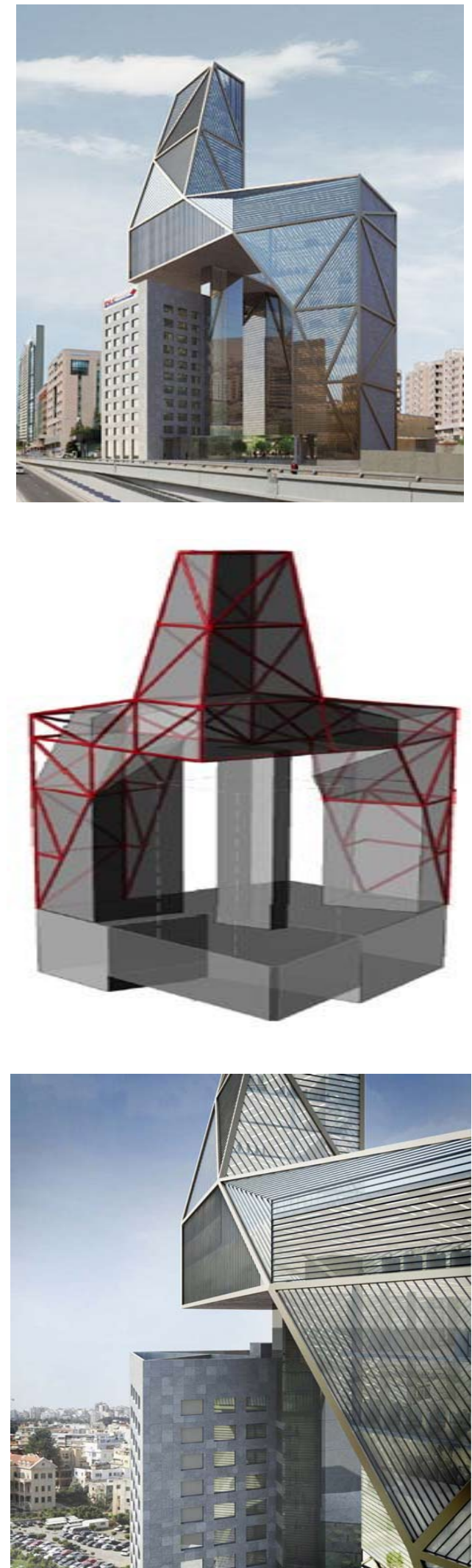

Figure 6. BLC bank Beirut, Lebanon, approved by LGBC (source: BLC official website)
More than 11 million buildings have been built according to these regulations and ranked using the articles 19-22. However, the operational rating is currently being developed (article 22), so the construction rating is valid for its lifespan. The system is based on four pillars - environmental, economic, social, and cultural [12]. The system consists of seven components (see table 3):

- Integrated development process: Encourage interdisciplinary teamwork to provide environmental management and quality throughout project life [26].

- Natural systems: maintenance, conservation, and restoration of natural environments and vital habitats of the region[11].

- Living buildings: Improving the quality and connection of outdoor and indoor spaces[9].

- Valuable water: Reducing water demand and encouraging efficient distribution and alternative water sources.

- Efficient energy: Energy saving using passive design measures, reduced demand, energy efficiency, and renewable resources.

- Retaining materials: Ensure that the "whole life" cycle is considered when selecting and identifying materials.

- Innovative practice: Encouraging innovation in building design and construction to facilitate market and industry developments.

Labeled 'without CFRP,' and the second group, 'with CFRP,' were loaded under hydrostatic pressure. Each group contained a perfect model and a perfect model

Table 3. Main criteria of MABHAS

\begin{tabular}{ll}
\hline \multicolumn{1}{r}{ Maximum score } & \multicolumn{1}{c}{ Criteria } \\
\hline 25 & (IDP) Integrated Development \\
& Process \\
25 & (NS) Natural systems \\
100 & (LB) livable buildings \\
10 & (PW) Valuable water \\
40 & (RE) Efficient energy \\
50 & (SM) Maintenance materials \\
10 & (IP) Innovative action \\
\hline 260 & Total \\
\hline
\end{tabular}

The overall goal of the MABHAS guidelines is to promote sustainable community development and improve the quality of life, and MABHAS ensures that residents benefit from urban elements that affect the quality of the urban and built-up form[12]

The first construction project related to MABHAS in Iran is the Milad tower in Tehran, the tallest advanced radio center, shopping mall, and entertainment facility in Tehran center [13]

Milad Tower of Tehran is a multi-purpose telecommunication tower located in the northwest of Tehran, Iran's capital. With a height of 435 meters, this tower is the tallest in Iran, [5] [6] the sixth tallest telecommunication tower globally, and the world's nineteenth tallest single structure. With 13,000 meters of infrastructure, this tower is the first among all telecommunication towers in the world regarding the area of use of the tower structure. [7] Due to its great height and different appearance, Milad Tower is visible from almost everywhere in Tehran and is one of Iran's capital (see fig. 7).

Milad Tower is located between a hill with an approximate area of 62 hectares located in the south of Shahrak Gharb neighborhood and north of Nasr alley (Gisha) in District 2 of Tehran Municipality. Geographically, the tower structure is 51 degrees, 22 minutes and 32 seconds east longitude, and 35 degrees, 44 minutes and 40 seconds north latitude. 
After examining 21 points and selecting 17 different points from Tehran, a group was selected, including the urban planning team, TV studies team, telecommunications, road and construction, economics, architecture, meteorology, traffic study, and geotechnical team. The main architectural and geoenvironmental advantages of this tower are:

- Public access with the desired level of service

- Located in one of the highest parts of the city

- Nobility over the most beautiful scenery and parts of the city

- Space needed for future performance and development

- $\quad$ Equipped with infrastructure

- A good distance to important terminals such as the airport and the railway station

- Create a TV cover

- Ability to communicate and direct vision with telecommunication stations

- Establishment among coordinated and non-disturbing uses

- Deployment along major city axes

- The potential for visual communication with other landmarks and spaces

- Ability to have green spaces or other elements of environmental design

- Milad Tower was built to construct a memorable structure as a symbol for Tehran's city and meet Tehran's telecommunication and television needs. The main functions of this tower are as follows:

- Create and expand wireless access network

- Creating the right infrastructure for new television systems

- Optimizing radio and television coverage

- Meteorological and traffic control applications
Expanding and optimizing the coverage of wireless and search networks

- Creating a tourist attraction and benefiting from tourist, commercial, and cultural spaces, revolving restaurant, special restaurant, open and closed viewing platform, artistic events, Gonbad Aseman, Museum of Iranian Celebrities, Museum of Municipal Gifts, Food Court, commercial units, exhibition spaces and facilities such as International Conference Center with 15 different halls, Dolphin Park, paintball, 3D game cinema, two cinemas, laser, traditional restaurant, waterfall cafe, etc.

\section{MENA Ranking Systems}

Sustainability is no longer an option but a fundamental necessity for maintaining a certain excellent existence for destiny generations. Consequently, governments' improvement of a brand new ranking machine that assigns their responsibilities to social desires is a neccesity[27]. The worldwide tendency and emphasis make certain that the preservation of environmental necessities becomes a global demand that places stress on the nations to build their ranking systems that serve their communities higher and, at the identical time, recognize their nature. International society should encourage these societies to accept it as a way of existence [28]. The above examples of ranking structures have shown excellent fulfillment and show each of these governments' interest to create their ranking system that reflects the global regulations of inexperienced buildings. Simultaneously, in-depth observation of the social network's cultural demands to reap sustainability alongside its three pillars [29].

Table 4. Green building rating systems in the MENA region

\begin{tabular}{|c|c|c|c|}
\hline Sustainability ranking system & Problems & Management organization & Certificate type \\
\hline $\begin{array}{l}\text { Global Sustainability } \\
\text { Assessment System (GSAS) }\end{array}$ & $\begin{array}{l}\text { The GSAS certificate is } \\
\text { divided into eight different } \\
\text { categories: } \\
\text { 1. Energy } \\
\text { 2. Water } \\
\text { 3. Internal environment } \\
\text { 4. The cultural and economic } \\
\text { value } \\
\text { 5. Site } \\
\text { 6. Urban connection } \\
\text { 7. Materials } \\
\text { 8. Management and operation }\end{array}$ & $\begin{array}{l}\text { Qatar Research } \text { and } \\
\text { Development } \\
\text { (GORD) }\end{array}$ & $\begin{array}{l}\text { Green building ranking } \\
\text { system that uses star systems } \\
\begin{array}{l}\text { beyond eight different } \\
\text { categories }\end{array}\end{array}$ \\
\hline $\begin{array}{l}\text { ARZ Green Building Ranking } \\
\text { System }\end{array}$ & $\begin{array}{l}\text { The Lebanese system has eight } \\
\text { modules for evaluating the } \\
\text { following: } \\
\text { 1. Energy performance } \\
\text { 2. Thermal energy } \\
\text { 3. Electricity } \\
\text { 4. Building cover } \\
\text { 5. Materials } \\
\text { 6. Internal air quality } \\
\text { 7. Water protection } \\
\text { 8. Operation and management }\end{array}$ & $\begin{array}{l}\text { Lebanese Green } \quad \text { Building } \\
\text { Council (LGBC) }\end{array}$ & $\begin{array}{l}\text { The non-profit organization, } \\
\text { but in collaboration with IFC, a } \\
\text { member of the World Bank } \\
\text { Group, has gained } \\
\text { international consultants' } \\
\text { rank. }\end{array}$ \\
\hline $\begin{array}{l}\text { Iranian national building } \\
\text { regulations }\end{array}$ & $\begin{array}{l}\text { Performance appraisal in: } \\
\text { 1. Integrated development } \\
\text { process } \\
\text { 2. Natural systems } \\
\text { 3. Viable communities } \\
\text { 4. Valuable water } \\
\text { 5. Efficient energy } \\
\text { 6. Preservatives } \\
\text { 7. Innovative action }\end{array}$ & Iranian Energy Association & 22 Articles of Regulations \\
\hline
\end{tabular}

It can come as a surprise to understand that the green constructing council (Iran) has published the names of the pinnacle ten green constructing Nation outdoor Iran, and in that listing, UAE (of MENA location) ranks ninth some of the top 10 nations [14]. This kind of record displays the level of consciousness of the importance of sustainability as a lifestyle, and the most important undertaking is to instill this concept in center jap society with all its old traditions that it has lived with for a long time [15]. It additionally indicates that Iranian standards shall be stepped forward to be more effective in comparison to different standards (see table 4). 

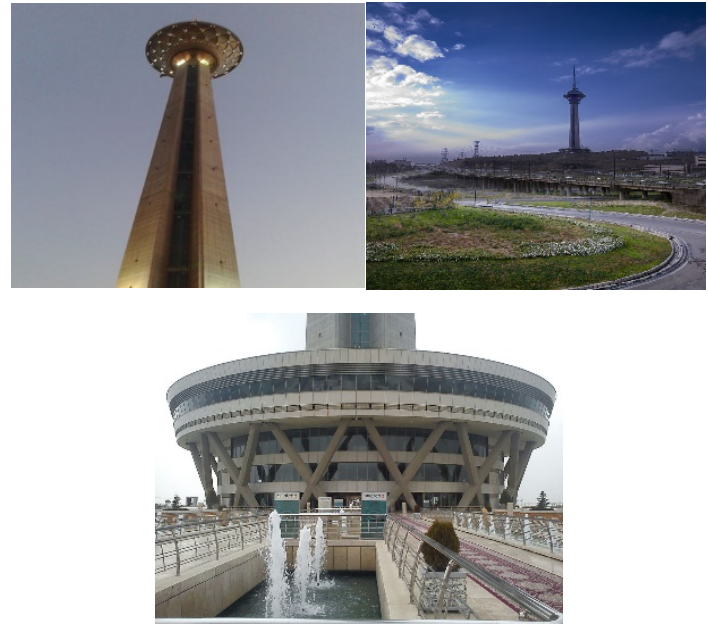

Figure 7. Milad Tower, the first national project constructed using the national MABHAS standard system (source: tower's official website)

Severa research was performed in Iran concerning sustainable development in diverse fields. However, the dedication or coordination of members of the family among them is remarkable and uncertain. Developing an opening between control, legal affairs, and the construction enterprise is key to attaining sustainability goals. Thus far, these three regions have no longer been studied simultaneously to observe their results on every different. Every player has acted independently and autonomously, so that damages the overall goals of sustainable development. Hence, a close operating relationship among the commercial and criminal sectors ought to be mounted. In other words, determining the legal safety required to put into effect engineering parameters is essential in thinking about a prudent approach to natural and monetary assets to save you similarly downturns. Further to the prison backing that can be carried out with various fields' cooperation, the guidelines of "cost and earnings" need to be determined for all stakeholders. In this, look at important factors associated with sustainable improvement in inexperienced buildings (buildings) from evaluating regional standards with every other.

With the help of comparing results, numerous practical techniques required in Iran were proposed and categorized according to their significance (see table 5). The impact of mandatory legal guidelines and guidelines became recognized because it was essential for Iran's sustainability. It's miles believed that powerful law can be done with numerous disciplines and coordination between the general public, administrative and personal sectors. Besides, sharing reports and expertise with worldwide institutions, including the sector inexperienced building Council and suitable schooling, can boost up sustainable development in Iran's construction industry. in keeping with the interviews, six difficult problems, which include felony obligations, consumer requests, standards, and codes, rating systems. Finally, the marketplace for enforcing inexperienced production in Iran ought to be taken into consideration.

Table 5. Recommendations for improvement of Iranian MABHAS regulations [5, 28-30]

Ranking Recommendations

1. Increasing the global awareness of the people about the effects of implementing different constructions on society, to gain their full support for the sustainable development plans. This global awareness will result in new demands, generation of new courses, and new educations will be needed in the construction field in the not so far future.

2. Making direct compulsory rules and regulations related to the construction by the legislative and administrative power and applying appropriate penalties to actions that contradict sustainable development goals. It should be noticed that green construction is a matter beyond environmental issues and cannot be addressed only by energy-saving codes/rules or by strategic environmental assessment (SEA) tools or policies. The lawmakers should consider all the 3 (or 4) pillars of sustainable development in this specific sector.

3. Cooperation between lawmakers and engineers, and managers: Each course's aim is, to some extent, different from the aim of the others. For instance, the aims of engineering and the law do not necessarily coincide. Although different courses have the same general goal, their different approaches to sustainability lead to many tensions among the managers, lawyers, and engineers. Their cooperation is urgently needed to reach a similar approach and similar understanding for similar goals.

4. Identification of the social and environmental indicators and factors for applying national, territorial, and local construction strategies.

5. Respecting the "Costs and Benefits" rule for the sake of financers, constructors, and consumers concerning a new risk-sharing policy. The "Business as Usual" approach will no longer work, and a new business vision is needed.

6. Considering and applying the results of future (futurology) and feasibility studies regarding client requests and future resources to construct green buildings.

7. Taking the private and general stakeholders' views and interested parties into account prevents stakeholders' future intervention and influential real and legal persons.

8. Coordination and cooperation between governmental and administrative sectors from one side and the private sectors to providing common constructing rules related to economy, technology, policy, and environmental aims. The creation of sustainable constructions and infrastructures and, in general, a sustainable society is a public duty.

9. Studying the long-term effects of constructions on the environment for the protection, reduction, and mitigation of the contingent damages and risks to the present and next generation.

10. Full efforts to find the affairs that positively or negatively influence the protection or the risks to the national resources. Codification of a new and up to a dated strategy for solid waste and wastewater treatment, energy-saving policy, and recycled materials in the construction industry.

11. Increasing the cooperation with international organizations (including; States, UN, and World Green Building Council) to protect the mutual interest globally. Sharing experiences with other developed countries can booster the process of Iran's sustainability. These cooperations can also result in the attraction of foreign direct investment.

\section{Conclusion}

Iranian society has tested that it may innovate in new ranking structures that respect its groups' tradition and have also executed sustainability and its three dimensions: the environmental measurement found in all preceding ranking systems. Specific classes, which include energy, performance, thermal energy, electric power, building coatings, materials, and water safety, are shown the financial measurement of which is shown in certain categories such as operation and control, and innovative practice, and the creativity of this country. This has seemed in the misplaced size in other international ranking structures and is in dire want in Iranian society, and sooner or later, inside the social measurement, which is a key thing of a sustainable society's fulfillment. The government of Iran has made splendid strides in setting up their rating systems that adapt their communities to the needs in their social and natural 
environment and all of the institutions' credentials. It forces creation to comply with and is the maximum critical step for a society that targets the patron's cultural values and can grow the public role's effectiveness inside the layout technique. In the end, preceding ranking systems had been more reputable, as they've proven that a strong foundation as a guide for developing ranking systems or encouraging different countries to have systems is their assessment of each's nature. Indicates and increases the significance of social components not simplest in Iran but additionally at some point of the MENA place.

\section{Declaration of Conflict of Interests}

The authors declare that there is no conflict of interest. They have no known competing financial interests or personal relationships that could have influenced the work reported in this paper.

\section{References}

[1.] Kong, X., Qiao, X., Yuan, G., Investigation of thermal environment and the associated energy consumption of transportation buildings along the expressways in the cold region of China: A case study, Energy and Built Environment 1 (2020) 278-287.

[2.] Li, B., You, L., Zheng, M., Wang, Y., Wang, Z., Energy consumption pattern and indoor thermal environment of residential building in rural China, Energy and Built Environment, 1 (2020) 327-336.

[3.] Bezai, N.E., Medjdoub, B., Al-Habaibeh, A., Chalal, M.L., Fadli, F. Future cities and autonomous vehicles: analysis of the barriers to full adoption, Energy and Built Environment (2020).

[4.] Karim, M., Pouya, M., Taheri, F., Azadi, H., Van Passel, S. Sustainability Indicators of Iran's Developmental Plans: Application of the Sustainability Compass Theory, Sustainability 7 (2015) 14647-14660.

[5.] Darabpour, M.R., Darabpour, M., Majrouhi Sardroud, J., Tabarsa, G., Smallwood, J., Practical Approaches Toward Sustainable Development in Iranian Green Construction, Civil Engineering Journal, 4 (2018).

[6.] Agyekum, K., Kissi, E., Danku, J.C., Professionals' views of vernacular building materials and techniques for green building delivery in Ghana, Scientific African (2020) e00424.

[7.] Lu, S., Liu, Y., Sun, Y., Yin, S., Jiang, X., Indoor thermal environmental evaluation of Chinese green building based on new index OTCP and subjective satisfaction, Journal of Cleaner Production 240 (2019) 118151.

[8.] Chethana, I.M., Illankoon, S., Lu, W., Optimising choices of 'building services' for green building: Interdependence and life cycle costing, Building and Environment 161 (2019) 106247.

[9.] Du, X., Zhang, Y., Lv, Z., Investigations and analysis of indoor environment quality of green and conventional shopping mall buildings based on customers' perception, Building and Environment 177 (2020) 106851.

[10.] Ofek, S., Portnov, B.A., Differential effect of knowledge on stakeholders' willingness to pay green building price premium: Implications for cleaner production, Journal of Cleaner Production 251 (2020) 119575.

[11.] Ade, R., Rehm, M., Buying limes but getting lemons: Cost-benefit analysis of residential green buildings -A New Zealand case study, Energy and Buildings 186 (2019) 284-296.

[12.] Li, S., Lu, Y., Kua, H.W., Chang, R., The economics of green buildings: A life cycle cost analysis of non-residential buildings in tropic climates, Journal of Cleaner Production 252( 2020) 119771.

[13.] Fan, K., Hui, E.C.M., Evolutionary game theory analysis for understanding the decision-making mechanisms of governments and developers on green building incentives, Building and Environment (2020) 106972.

[14.] Liu, G., Li, X., Tan, Y., Zhang, G., Building green retrofit in China: Policies, barriers and recommendations, Energy Policy 139 (2020) 111356.

[15.] Wu, X., Lin, B., Papachristos, G., Liu, P., Zimmermann, N., A holistic approach to evaluate building performance gap of green office buildings: A case study in China, Building and Environment 175 (2020) 106819.

[16.] Cohen, C., Pearlmutter, D., Schwartz, M., Promoting green building in Israel: A game theory-based analysis, Building and Environment 163 (2019) 106227.

[17.] Yas, Z., Jaafer, K., Factors influencing the spread of green building projects in the UAE, Journal of Building Engineering 27 (2020) 100894

[18.] Lee, J.-Y., Wargocki, P., Chan, Y.-H., Liu Chen, Tham, K.-W., How does indoor environmental quality in green refurbished office buildings compare with the one in new certified buildings?, Building and Environment 171 (2020) 106677.

[19.] Houghton, A., Castillo-Salgado, C., Analysis of correlations between neighborhood-level vulnerability to climate change and protective green building design strategies: $\mathrm{A}$ spatial and ecological analysis, Building and Environment 168 (2020) 106523.

[20.] Varma, C.R.S., Palaniappan, S., Comparision of green building rating schemes used in North America, Europe and Asia, Habitat International 89 (2019) 101989.

[21.] Chethana, I.M., Illankoon, S., Lu, W., Cost implications of obtaining construction waste management-related credits in green building, Waste Management 102 (2020) 722-731.

[22.] Li, Q., Long, R., Chen, H., Chen, F., Wang, J., Visualized analysis of global green buildings: Development, barriers and future directions, Journal of Cleaner Production 245 (2020) 118775.

[23.] Yin, S., Li, B., Xing, Z., The governance mechanism of the building material industry (BMI) in transformation to green BMI: The perspective of green building, Science of The Total Environment 677 (2019) 19-33.

[24.] Madad, A., Gharagozlou, A., Majedi, H., Monavari, S.M., Considering water ecological aspects in developing a quantitative climatic model of urban green building using monetary valuations, Ecological Economics 169 (2020) 106562.

[25.] Gui, X., Gou, Z., Association between green building certification level and post-occupancy performance: Database analysis of the National Australian Built Environment Rating System, Building and Environment 179 (2020) 106971.

[26.] Adekanye, O.G., Davis, A., Azevedo, I.L., Federal policy, local policy, and green building certifications in the US, Energy and Buildings 209 (2020) 109700.

[27.] Qiao, R., Liu, T., Impact of building greening on building energy consumption: A quantitative computational approach, Journal of Cleaner Production 246 (2020) 119020.

[28.] Jiang, B., Song, Y., Li, H.X., Lau, S.S.-Y., Lei, Q., Incorporating biophilic criteria into green building rating tools: Case study of Green Mark and LEED, Environmental Impact Assessment Review 82 (2020) 106380.

[29.] Geng, Y., Lin, B., Zhu, Y., Comparative study on indoor environmental quality of green office buildings with different levels of energy use intensity, Building and Environment 168 (2020) 106482

[30.] Chi, B., Lu, W., Ye, M., Bao, Z., Zhang, X., Construction waste minimization in green building: A comparative analysis of LEEDNC 2009 certified projects in the US and China, Journal of Cleaner Production 256 (2020) 120749.

\section{How to Cite This Article}

Norouzi, N., Fani, M., and Nasiri, Z., The development of a Nexus based green architecture ranking system in Iran, Civil Engineering Beyond Limits, 2(2021), 19-26. https://doi.org/10.36937/cebel.2021.002.003 